\title{
RISK MANAGEMENT IN CONSTRUCTION PROJECTS USING QUANTITATIVE METHOD
}

\author{
Meti Retesh Shivasangappa ${ }^{1}$, Sneha.K.Sawant ${ }^{2}$, Smita Pataskar ${ }^{3}$ \\ ${ }^{1}$ Pursuing ME Construction Management, D.Y. Patil College of Engineering, Akurdi, Pune \\ ${ }^{2}$ Assistant Professor, D.Y. Patil College of Engineering, Akurdi, Pune \\ ${ }^{3}$ Assistant Professor, D.Y. Patil College of Engineering, Akurdi, Pune
}

\begin{abstract}
The center part of the study is to deal with various risk encountered in construction projects. It hasbeen recognized as important part of project life cycle in order to achieve the objectives in terms of time, quality, cost and scope. Based on the conditions of construction projects this study identifies and analyze them with appropriate risk managing techniques to give solution to various risks.

All analysis are based on theoretical background regarding risk, risk management process and project life cycle approach in the construction sector. This study presents the risk management in the pre-execution stages, execution, post -execution of project life cycle of construction project. This study proposes to apply risk managing techniques which includes well-documented procedure for the one stop solution all types of hazard most likely to occur during any construction.
\end{abstract}

Keywords - Risk management, Risk identification. Risk classification, Risk analysis and Risk response, ATMA

\section{INTRODUCTION}

\subsection{Risk Management}

Project risk management is the art and science of managing risk caused by unforeseen (uncertainties) which may require deviation from the plan of approach and therefore may affect the project objective set during initial stage. It involves various steps such as identification, analyses, mitigation and controlling them.

Risk management can be described as the systematic way of looking into areas where the risk is commonly encountered and how it can be treated. It is management tool which helps in identifying the uncertainties and develop a strategic response to mitigate it. The systematic process of risk management is associated with risk classification,risk identification, risk analysis and risk response. Risk response can be handled with four action accept, transfer, mitigate and avoid (ATMA).Risk management is a such an effective method is does not only help to understand various risk but even helps in managing risks in various stages of the project.

\subsection{Necessity of Risk Management}

Construction conditions vary from region to region, project to project, time to time. Few projects are complicated and encounter more risks. Few risk can occur on site and few in planning stages. Hence various parties sign in the contract and agree to follow the conditions as per the contract. Due certain obstacles and problems project can face serious issue such as delay and idling of resources. Hence the project may get complex. To solve these risks encountered risk management technique was introduced.
Risk identification and planning helps to enhance profitability in the project. Construction company has many practical risks. Hence companies have to plane for hazard occurring during the project execution stage depending on the past experience safety and environmental risks have to planned in initial stage of the project and pre-cautionary step has to be taken.

\section{OBJECTIVE OF STUDY}

Although this work is in its in early stages, it is anticipated that it will cover some or all of the following objectives.

Phase-I

- Risk Identification with brainstorming sessions, expert advice, past experience, interviews.

- Group the various risks caused during the preexecution.execution and post execution stages and risk owners responsible for them.

- Prioritization of risks by quantitative method.(analysis)

Phase-II

- Handling risk by (ATMA) avoidance, transfer, mitigation, accept.

- Rank the risks encountered according to average risk factor.

\section{METHODOLOGY}

The suggested research objectives and subsequent questions listed at the beginning at this document, require the use of different data sources and research methods. Thus the research is expected to employ varies different methods particular to each facet of the research problems. 
The research is expected to be done in several stages determined by the achievement of the predefined objectives. As seen at this very early stage it is expected that the possibilities of this work include the following methodologies.

- A significant portion of what is known on the topic will be obtained by interviewing some of the head construction managers and various risk's are grouped associated with construction projects.

- Then the following risk's are subjected for analysis. Depending on the type of risk's either qualitative or quantitative assessment is performed. Here its quantitative method.

- Qualitative and quantitative have several types of techniques. With these techniques all risk's can be Rated and prioritized.

- $\quad$ Through the questionnaire answered by the construction manager and site engineer we get to know the rating of probability and impact of various risks. i.e all risks are rated on a scale of $0-100$.

- Then, next to get significance or importance index, products of probabilityand impact are taken dividing it by 100 .
For example,

Risk of time and cost overrun,

Probability $=90 \quad$ impact $=86$

$(90 * 86) / 100=77.40$

Therefore importance index $=77.40$

- Risks are ranked according to the average risk factor.

Average risk factor $=\sum \mathrm{I} . \mathrm{I} / \mathrm{n}$

Where,

I.I=significanceindex or importance index $\mathrm{n}=$ number of risks.

Method of ranking various risks:

i) Probability index will arranged in descending order and highest will be ranked 1 and lowest will ranked last.

ii) When same impact index is observed, give the same rank to both risks and omit the next rank.

iii) Probability index with high rate will be ranked low and probability index with low rate will be ranked high.

Table-1: Risk-Allocation

\begin{tabular}{|c|c|c|c|c|c|c|c|}
\hline \multirow[t]{2}{*}{ S1. No } & \multirow[t]{2}{*}{ Possible Risks } & \multicolumn{3}{|c|}{ Occurance } & \multicolumn{3}{|c|}{ Risk Allocation } \\
\hline & & \begin{tabular}{c|} 
Pre- \\
Execution
\end{tabular} & Execution & $\begin{array}{c}\text { Post } \\
\text { Execution }\end{array}$ & Employer & PMC & Contractor \\
\hline 1 & Tight Project Schedule & & yes & & & $y$ & $\mathrm{y}$ \\
\hline 2 & Project Funding Problems & yes & yes & & $y$ & & $y$ \\
\hline 3 & Variation by client & & yes & & & $\mathrm{y}$ & $y$ \\
\hline 4 & Design variation & & yes & & $\mathrm{y}$ & $y$ & $\mathrm{y}$ \\
\hline 5 & inadequate program scheduling & & yes & & & $\mathrm{y}$ & \\
\hline 6 & Inadequate site information & & yes & & & $y$ & $y$ \\
\hline 7 & Incomplete/Incaccurate cost estimation & & yes & & $\mathrm{y}$ & & \\
\hline 8 & Contractor's poor management ability & & yes & & & $\mathrm{y}$ & $\mathrm{y}$ \\
\hline 9 & Contractor's difficulty in reimbursement & & & yes & & $y$ & $y$ \\
\hline 10 & Poor competency of laboureres & & yes & & & & $y$ \\
\hline 11 & Unavailability of sufficient managers & & yes & & $\mathrm{y}$ & $\mathrm{y}$ & $\mathrm{y}$ \\
\hline 12 & Major equipments do not have insurance & & & & & $\mathrm{y}$ & $\mathrm{y}$ \\
\hline 13 & Inadequate safety measures & & yes & & & $\mathrm{y}$ & \\
\hline 14 & Lack of readility available utility & & yes & & & & $\mathrm{y}$ \\
\hline 15 & Unavailability of sufficient skilled labourers & yes & yes & & & & $\mathrm{y}$ \\
\hline 16 & $\begin{array}{l}\text { Legal issues due to unlawful disposal of construction } \\
\text { waste }\end{array}$ & & yes & yes & & & y \\
\hline 17 & Air pollution caused by construction & & yes & yes & & $\mathrm{y}$ & $\mathrm{y}$ \\
\hline 18 & Noise pollution caused by construction & & yes & & & $y$ & $y$ \\
\hline 19 & Water pollution caused by construction & & yes & & & $\mathrm{y}$ & $\mathrm{y}$ \\
\hline 20 & Low Management competency of sub contractors & & yes & & & & $\mathrm{y}$ \\
\hline 21 & Suppliers incompetency to deliver materials on time & & yes & & & & $\mathrm{y}$ \\
\hline 22 & Bureaucracy of govt. & yes & & & $\mathrm{y}$ & & \\
\hline 23 & Excessive procedures for govt approvals & yes & & & $\mathrm{y}$ & & \\
\hline 24 & Price inflation of construction materiials & & yes & & $\mathrm{y}$ & & $\mathrm{y}$ \\
\hline 25 & Act of God & & yes & & $\mathrm{y}$ & & $\mathrm{y}$ \\
\hline 26 & Adverse weather conditions & & yes & & $\mathrm{y}$ & & $\mathrm{y}$ \\
\hline
\end{tabular}


Table-2: Risk Response Startegies Plan

Risk response

strategy

Risk-handling method

Risk avoidance $\quad$ Increase unit cost or overhead

- Develop alternatives for risk events

- Remove risk events by avoiding them

Risk transfer

- Use insurance companies

- Make a subcontract

Risk mitigation - Train or educate employees

- Provide best supplies (e.g., computer, software, equipment, and so on)

- Develop a strategic staffing plan

- Use proven construction methods and materials

- Safeguard both workers and property

Risk retention Prepare contingency planning

- Accept profit losses
Table-3: Risk Handelling Method

\begin{tabular}{|c|c|c|}
\hline \multirow{3}{*}{$\begin{array}{c}\text { Response } \\
\text { code }\end{array}$} & Risks & Risk handelling method \\
\hline & 1. Risk of time and cost overrun & RA-1,RA-2 \\
\hline & 2. Risk of design variation by client & RA-2 \\
\hline & 3. Risk of receiving inadequate site information & $\mathrm{RM}-1$ \\
\hline \multirow{2}{*}{ RA-1 } & 4. Risk of selecting contractors incapable of handling project well & $\mathrm{RM}-1, \mathrm{RM}-2$ \\
\hline & 5. Risk of scope changes & RM-3 \\
\hline RA-2 & 6. Risk of decline in quality of work due to change in top management & RR-1 \\
\hline \multirow{2}{*}{ RA-3 } & 7. Risk of unforeseen circumstances due to lack of communication & $R R-1$ \\
\hline & 8. Risk of delay from consultant/contractor & RR-1,RR-2 \\
\hline \multirow{2}{*}{ RT-1 } & 9. Risk of delay due delay in obtaining permits & RR-1,RR-2 \\
\hline & 10. Risk of unrest due to labour strikes & RR-2 \\
\hline RT-2 & 11. Risk of dispute between archtects and structural ençineers & RR-2,RA-1 \\
\hline \multirow{2}{*}{ RM-1 } & 12. Risk of cost variation due to changes in cost of procurement & RT-1 \\
\hline & 13. Risk in execution due to adverse weather conditions & RT-2 \\
\hline \multirow{3}{*}{ RM-2 } & 14. Risk in execution due to social unrest & RT-2 \\
\hline & 15. Risk in execution due to war & $\overline{R T}-2$ \\
\hline & 16. Risk of delay due to excessive red tapes in govt. proceedings & RA-3 \\
\hline \multirow{2}{*}{ RM-3 } & 17. Risk of rework due to defective construction work & RM-3 \\
\hline & 18. Risk of payment delay & RM-3 \\
\hline \multirow{3}{*}{ RM-4 } & 19. Risk of restricted availability of site & $\mathrm{RM}-3$ \\
\hline & 20. Risk of inadequate safety measures on site & $\mathrm{RM}-3, \mathrm{RM}-4$ \\
\hline & $\begin{array}{l}\text { 21. Risk of complaints from neighbours due to pollution caused (air, water and } \\
\text { noise) }\end{array}$ & RR-1 \\
\hline RM-5 & 22. Risk of not meeting accelerated deadlines & $R R-1$ \\
\hline \multirow{2}{*}{ RR-1 } & 23. Risk of sudden change in govt. regulations & RR-1,RR2 \\
\hline & 24. Risk of damaging underground utility lines during excavation & $\mathrm{RR}-1, \mathrm{RR}-2$ \\
\hline \multirow{2}{*}{ RR-2 } & 25. Risk of execution due to poor quality of procured material & RT-1,RR-1,RR-2 \\
\hline & 26. Risk of opposition from local population & RT-1,RT-2,RM-3 \\
\hline
\end{tabular}

Table-4: Questionnaire Analysis

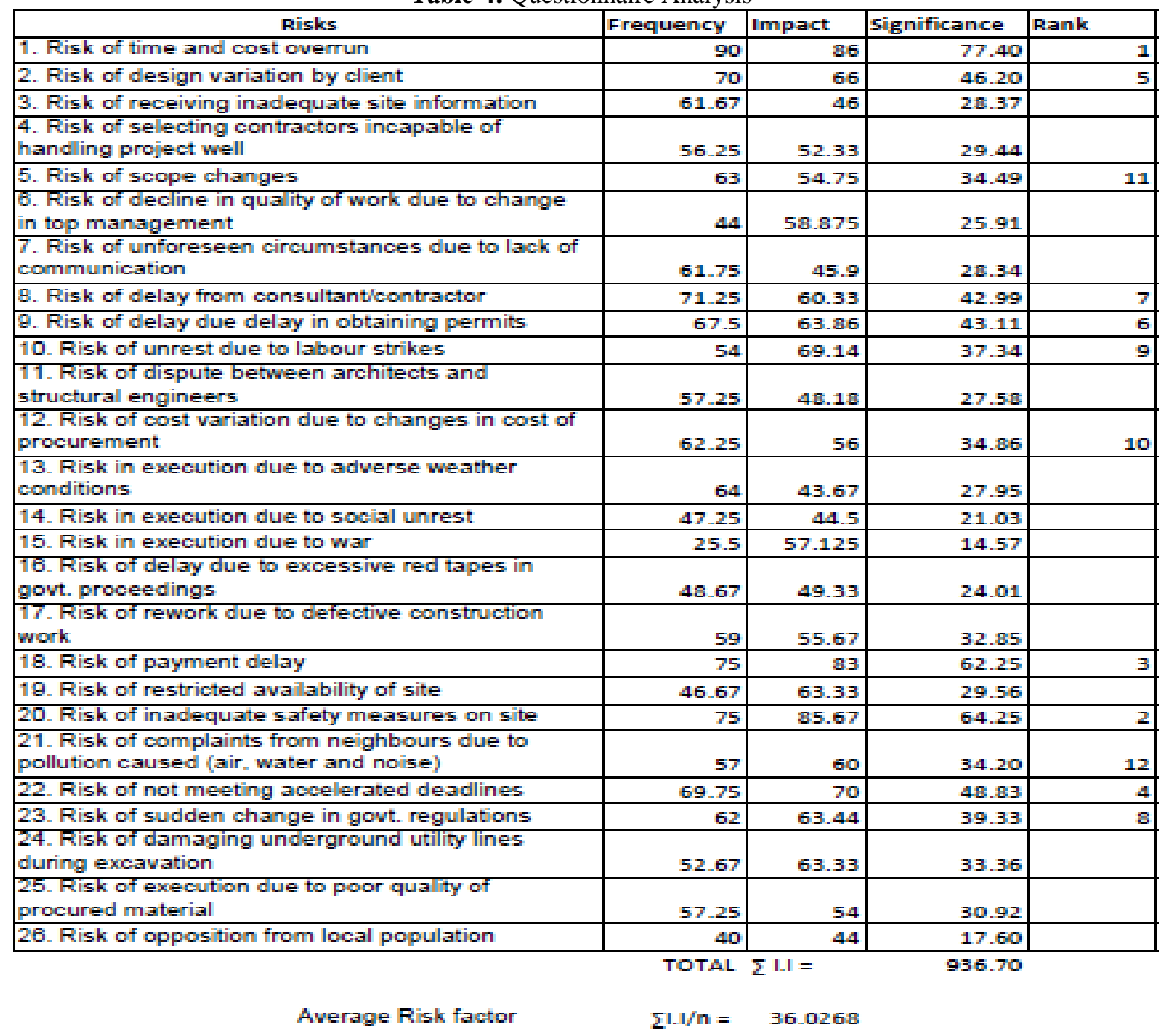




\section{RESULTS}

- Classification of risks according to the projectlife cycle.

- Prepared mathematical modeling and calculated the average risk factor, through which we canunderstandnumber of risks hazardous to construction project w.r.t to average risk factor.

- To enhance profitability in construction by maintaining the schedule and plan of the project.

- To plan for risks in initial stage of the project.

- Prepare for risk handling method by having astrategic response without wasting time at the point of emergency.

\section{CONCLUSION}

- According to studies conducted, risk management has to be followed by the all firms to maintain the decorum of construction site and organization.

- The team working on the project should have ability to look through the contract and site details and recognize the risks.

- It's better to know and plan for risk in the initial stage of the project and Implement that technique at the time of emergency.

- The mitigation method may vary from site to site depending on the geographical factor.

- The charts formed may be helpful to similar construction projects and shall no doubt be of use.

\section{REFERENCES}

[1] A Guide to the Project Management Body of Knowledge, (1996), PMI, ProjectManagement Institute.2.

[2] Alfredo del Can, and M. Pilar de la Cruz, "Integrated Methodology for Project Risk Management", Journal of Construction Engineering and Management, ASCE, December 2002, 473-4854.

[3] DaudNasir, Brenda McCabe and Loesie Hartono "Evaluating Risk inConstruction-Schedule Model (ERIC-S) Construction Schedule Risk Model"Journal of Construction Engineering and Management, ASCE, Vol. 129, No. 5,October, 2003, 518-5278.

[4] http://ijiset.com/vol3/v3s5/IJISET_V3_I5_10.pdf

[5] Protocol to Enhance Profitability by Managing Risks in Construction Projects

[6] International Journal of Innovative Technology and Exploring Engineering (IJITEE) ISSN: 2278-3075, Volume-3, Issue 5, October 2013 YoojungYoon, A.M.ASCE1; Ziad Tamer2; and MakarandHastak, M.ASCE3.

[7] International Journal of Innovative Research in Advanced Engineering (IJIRAE) ISSN: 2349-2163 Issue 4, Volume 2 (April 2015).

[8] Risk Management Practices in a Construction Project - a case study Master of Science Thesis in the Master's Programme Design and Construction Project Management. 